\title{
The Sedimentary Geology, Remote sensing, Geomorphology and Petrology of Miocene to Late Pliocene sediments in District Sudhunhoti and Poonch, Azad Jammu and Kashmir, Pakistan \\ Muhammad Yasin', Syed Muhammad Kamran Ali², Munir ul Hassan Munir², Muhammad Ishfaque ${ }^{3}$
}

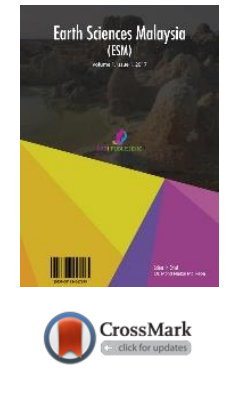

1Pakistan Journal of Geology, *Corresponding Author Email: Rajayasinkhan@gmail.com

Institute of Geology, University of Azad Jammu and Kashmir, Muzaffarabad, Pakistan

${ }^{3}$ MS Scholar, University of Azad Jammu and Kashmir, Muzaffarabad, Pakistan

This is an open access article distributed under the Creative Commons Attribution License, which permits unrestricted use, distribution, and reproduction in any medium, provided the original work is properly cited

\section{ARTICLE DETAILS}

Article history:

Received 24 October 2016 Accepted 7 December 2016 Available online 3 January 2017

Keywords:

embarked,sub-Himalayas, mutilated,pebble imbrications, accessory minerals, prima facie

\section{ABSTRACT}

A research work was embarked in the area in order to understand the sedimentary geology, remote sensing geomorphology and petrology of the district Sudhunhoti and Poonch, Azad Jammu and Kashmir, Pakistan. For this purpose the Khirik, Muttail Maira, Thandi Kassi, Kothian, Hill, Maidan, Rhera, Dar, Sairhan, Afsar Market, Gorah, Nakkar bazaar, Gui Nala, Bandia, Mang, Jassa Pir and Thorar areas were mapped and interpreted on Digital Elevtion Model (DEM) in the sub-Himalayas of Pakistan. The area has been mutilated by folding and faulting governed by orogenic forces. The clastic rocks exposed in the area are sandstone, siltstone, claystone and conglomerates. The sedimentary structures include planner bedding, ripple marks and pebble imbrications. The rip ups of siltstone and clay occur at the base of sandstone. The sandstone of Nagri Formation is well exposed in the area. The sandstone contains clasts of volcanics, quartzites, schist and chert. The sandstone of Dhok Pathan Formation is medium to coarse grained. It contains clasts of gneiss, schists, quartzites, granite, carbonate and marble. The sandstone is comprised of mineral quartz ( $23 \%$ to $45 \%$ ), feldspar (3\% to $13 \%$ ) and the rock fragments of igneous, metamorphic and sedimentary rocks. The accessory minerals in the Nagri Formation sandstone are biotite ( $1 \%$ to $3 \%$ ), muscovite (up to $2 \%$ ), tourmaline (few traces) and zircon $(1 \%)$. The cementing material in the rock is calcite $(6 \%$ to $18 \%)$ and silica $(2 \%$ to $3 \%)$. The modal mineralogical data of the sandstone shows that the sandstone is lithic arenite and lithic graywacke. The modal data reveal that the detritus was derived from the rising Himalayas in north of the area. The sedimentary structure and the conglomeration is the prima facie for the fluviatile origin of rocks.

\section{Introduction}

The study area with cardinal points between latitude $33^{\circ} 45^{\prime} 00^{\prime \prime} \mathrm{N}$ to $33^{\circ}$ $51^{\prime} 30^{\prime \prime} \mathrm{N}$ and Longitude $73^{\circ} 35^{\prime} 36^{\prime \prime} \mathrm{E}$ to $73^{\circ} 45^{\prime} 00^{\prime \prime} \mathrm{E}$ (Fig. 1) possesses glen valleys, solitude mountains, defile mountaineous passes, fertile lands, recondite places and forests. The Khirik, Muttail Maira, Thandi Kassi, Kothian, Hill, Maidan, Rhera, Dar, Sairhan, Afsar Market, Gorah, Nakkar bazaar, Gui Nala, Bandia, Mang, Jassa Pir and Thorar areas of the District Sudhunhoti and Poonch, Azad Jammu and Kashmir, Pakistan on map (Fig.1; Fig.2) include Miocene to Pliocene sedimentary rock sequence and recent alluvium exposed along the eastern limb of Hazara Kashmir Syntaxis (HKS) in the Sub-Himalayas (Baig and Lawrence, 1987). The rock sequence was formed by the Indian-Eurasian collision (Shah, 2009). The area adjacent to the Muttail Maira has also been convulsed by the devastating earthquake of 7.6 magnitude during October, 8, 2005. The study area starts $11 \mathrm{Km}$ South West of Rawalakot at Muttail Maira and extends to the Mang.

\section{Previous Work}

The geology of the region was studied (Wadia, 1928; Chaudhary and Ashraf, 1980) during the field surveys before embarkments of projects in the region (Yasin, 2014; Akhtar et al., 2015) and adjoing areas (Kamran et al., 2010).

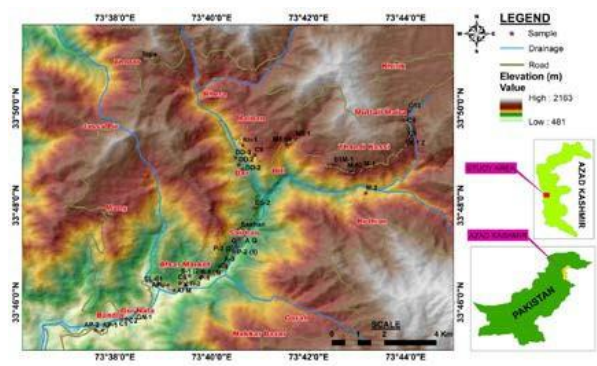

Fig. 1 The panoramic bird's eye view of the project area with the location of samples being stenciled on the Digital Elevation Model (Yasin, 2014).

\section{Material and Methods}

The area was cut across the mountains along road side during 90 days field work as oblonged on the map (toposheet number 43/G-9, Survey of Pakistan; Fig. 1; Fig. 2) being compiled on Arc GIS 10.1 programmed software. The stratigraphy and structure of the region are shown on a map (Fig. 2). In addition, the remote sensing technique such as the Digital Elevation Model (DEM) provided the panoramic bird's eye view of the geomorphic features such as recondite places, defile valleys and insurmountable mountaineous tops (Fig. 1). The height of 216, 3 have been paced out at the top of Jassa pir (Fig. 1). Beside toposheet, the Brunton compass, Global Positioning System (GPS), geological hammer, handlense and measuring tape were the other field appliances. The thickness of lithologies (Fig. 3) was gauged by means of the tape compass clinometer method. Atleast 30 rock samples of sandstone (Table. 1:Table. 2) were selected for thin section study and prepared by crushing and grinding at Geoscience Laboratory Islamabad, Pakistan. The positions of rock samples (Fig. 1) as determined through the Global Positioning System (GPS) were stenciled on Digital Elevation Model (DEM). The mineral grains in these samples were identified under microscope. The percentage of minerals as numerated through visual acuity has been enumerated under Tables $1 \& 2$. The thin section study was helpful in classifying rocks, in determining provenances and tectonic settings (Fig. 9). The planner bedding (Fig. 4), ripple marks (Fig. 5), pebble imbrications (Fig. 6) and carbonate concreations (Fig.7) are the quintessence of primary sedimentary structures of the area. 


\section{Results and Discussions}

\subsection{Geological Structure and stratigraphy}

The area has been mutilated through folds and faults (Fig. 2) governed by tectonic forces and landslides triggered by the heavy rainfall. The folds of the area include Mang syncline, Sairhan anticline and Thandi Kassi anticline and Syncline. The Riasi Thrust is the only fault of the region (Fig. 2). The foot wall, hanging wall blocks and fault plane can be distinguished easily in Maidan. The composite landslides and fractures are other evidences of deformations. The water exuded through the inlet of fractures is the evidence of deformation in the area (Yasin, 2014).

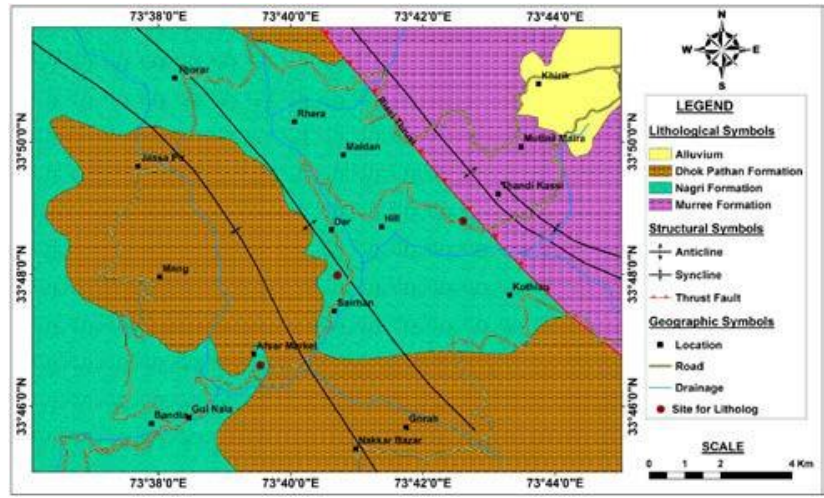

Fig. 2 The geological mapping on the toposheet number 43/G-9, Survey of Pakistan using Arc GIS 10.1 programmed software (Yasin, 2014).

\subsubsection{Murree Formation}

The name Murree Formation is originally proposed by Wynne (1874) as "Mari group", which is finally approved by the Stratigraphic Committee of Pakistan. The type section of formation lies to the north of Dhok Makai, Attock district, Pakistan. The sandstone, mudstone, clay stones and conglomeration of rock fragments formed the main domain of lithology. The sandstone is tinctured with dark gray to weathered black colour in Muttial Maira, Police Choki and Maidan to gray in Thandi Kassi and light green in Maira (Yasin, 2014). The sandstone has medium and coarse texture, thick bedding with wood fossils, especially in Maidan area. The shale is thinly bedded, calcareous and shows a variation in color from brown in Thandi Kassi and Maidan, cream in Police Choki to green and yellow in Maira. The siltstone interbedded with shale shows a great variation in color from green in Maidan to green, red and cream brown in Maira. Moreover, the siltstone is mostly thick bedded and jointed in Maira. The clays are mostly red and maroon in Muttail Maira to brown in Thandi Kassi. The conglomerates in the sandstone are clasts of extraformational particles like quartzite and also rip ups of shale. Field evidences reveal that the formation is a fluvial deposit. The formation has faulted contact with Nagri Formation. The age of the formation is early Miocene (Shah, 2009)

\subsubsection{Nagri Formation}

The name "Nagri Formation" as accepted by Stratigraphic Committee of Pakistan is first proposed by Lewis (1937). The type section of formation lies in Nagri village of Attock district. In Project area, the lithology of formation includes sandstone, shale and clays and conglomerates in scanty amount (Fig. 3). The sandstone is almost light gray in colour. The primary sedimentary structure like planer bedding (Fig. 4) and ripple marks (Fig. 5) are common. In Thorar, the sandstone is coarse grained, exhibits salt and pepper texture and cemented with calcite. In Dar, the sandstone is micaceous, thick bedded to massive and jointed. The carbonate concreations (Fig. 7) are present in shale exposed in Maidan along the foot wall of fault (Fig. 2). The conglomerates are clasts of both extraformational particles and intraformational siltstone. The rip ups of siltstone and shale are also common. The quartzite is the most dominant clasts in extraformational type. In Dar, clasts of quartzite, volcanics and intraformational siltstone represents conglomeratic level. In other regions the clasts of sandstone, limestone, granite, quartzite, phyllite and dolomite are observed.

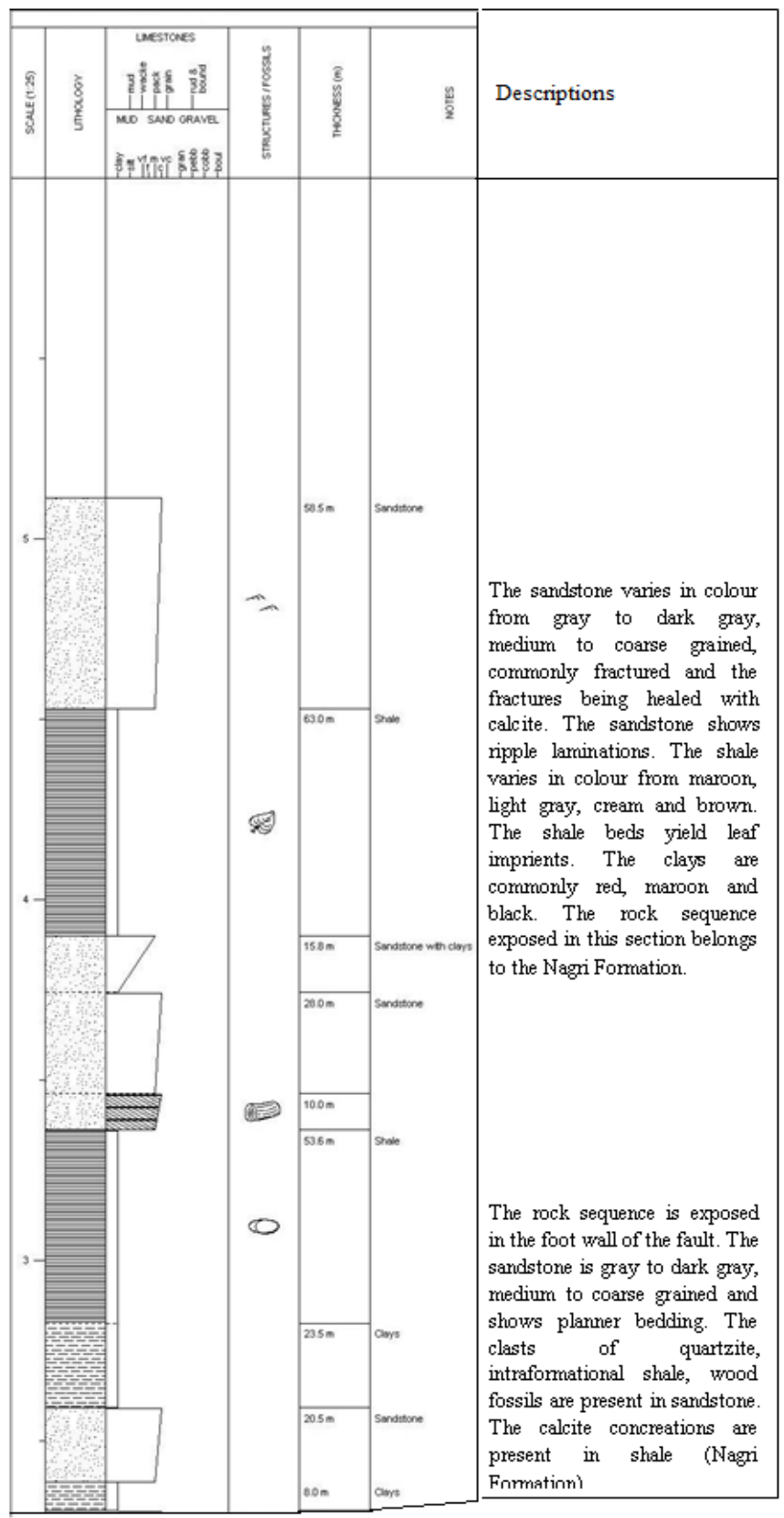

Fig. 3 A stratigraphic section of the Nagri Formation measured along the foot wall in Maidan and Rhera area.

The shale shows a variation in color from brown in Thorar to red in Sairhan, maroon and black in Dar. The plants remains like leaf fossils (Fig. 3) are also present. The black color in the rock is due to the presence of organic matter. Minor amount of pyrite is also present.

In Dar, the wood and leaf fossils are observed. The age of the formation is late Miocene (Shah, 2009).

\subsubsection{Dhok Pathan Formation}

The name Dhok Pathan Formation is proposed by Cotter (1933) and finally approved by the Stratigraphic Committee of Pakistan. The type section of formation lies in the village of Dhok Pathan (Lat. 33 $07^{\prime} \mathrm{N}$ : Long. $72^{\circ} 14^{\prime} \mathrm{E}$ ) in Attock district. The formation is composed of sandstone, clays and conglomerates (Yasin, 2014). In the project area the formation has a typical sequence of alternate beds of sandstone and clay (Yasin, 2012). The sandstone clay ratio in Kashmir Basin is 50:50. The sandstone is mostly dark gray and black. The sandstone is loose, friable, thick bedded and calcareous (Yasin, 2014). The clays are mostly brown, reddish brown and yellowish gray in colour. The clays are occasionally calcareous. The siltstone is yellowish brown. The conglomerate lenses are also present. The distribution of conglomerates increases towards the top of the formation. In Jassapir, clasts of volcanics, granite, granite-gneisses, marble, dolomite, phyllite, 
granite gneiss and intraformational siltstone (Fig. 6) are innumerable and disseminated in all directions. The clasts of pebbles in sandstone bed show imbrications (Fig. 6). The Formation is well exposed in the Mang (Fig. 2). The sandstone is mostly thick bedded and interbedded with shale in Nakkar Bazar. The shales are thick bedded in Nakkar Bazar.

A rich faunal diversity from the adjacent Kohat-Potwar basin was reported by different authers. The fauna are indicative of an early to middle Pliocene age (Shah, 2009).

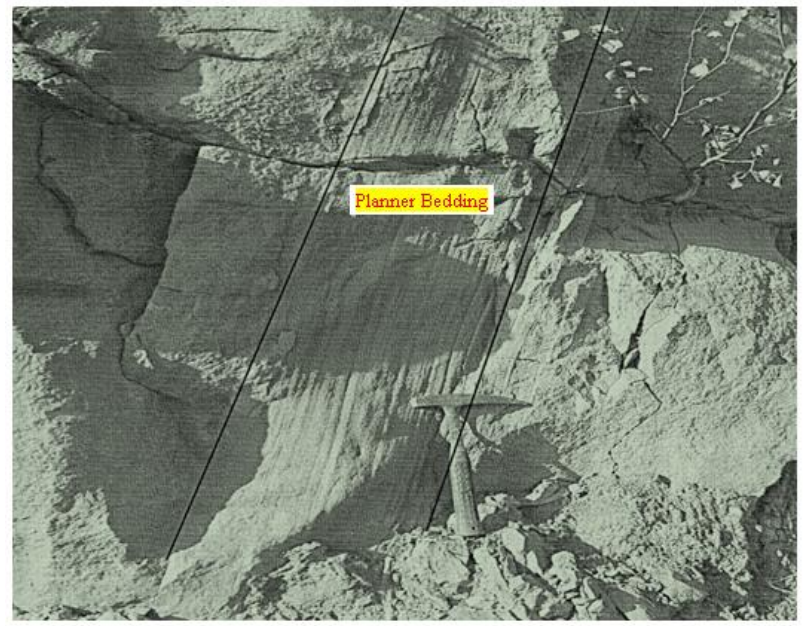

Fig. 4 The planner bedding in Nagri Formation's sandstone, Maidan, Poonch area, Pakistan (Yasin, 2014).

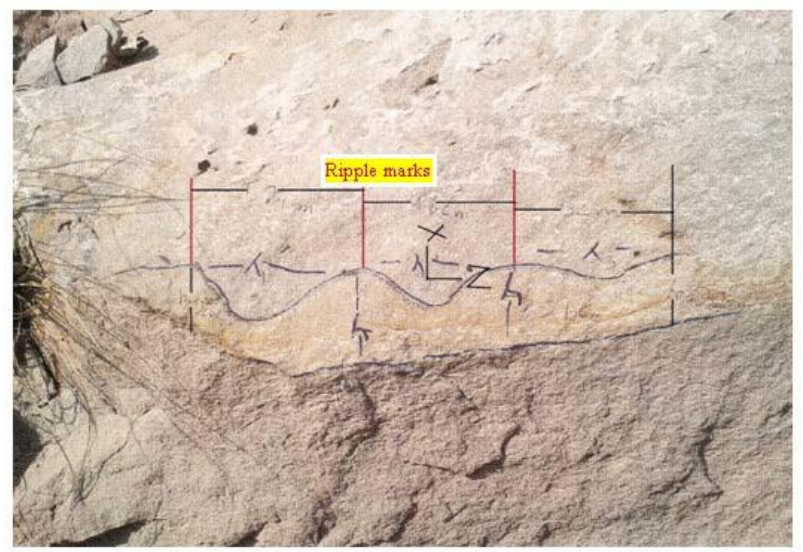

Fig. 5 The ripple marks in Nagri Formation, Dar, Azad Jammu and Kashmir, Pakistan (Yasin, 2014).

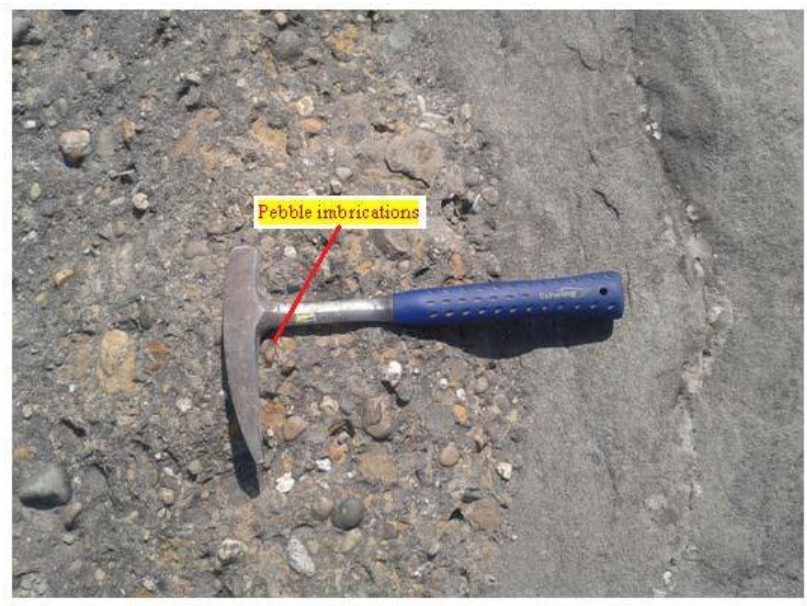

Fig. 6 The pebble imbrications and conglomeration in Dhok Pathan Formation, Jassa Pir, Sudhunoti, Pakistan.

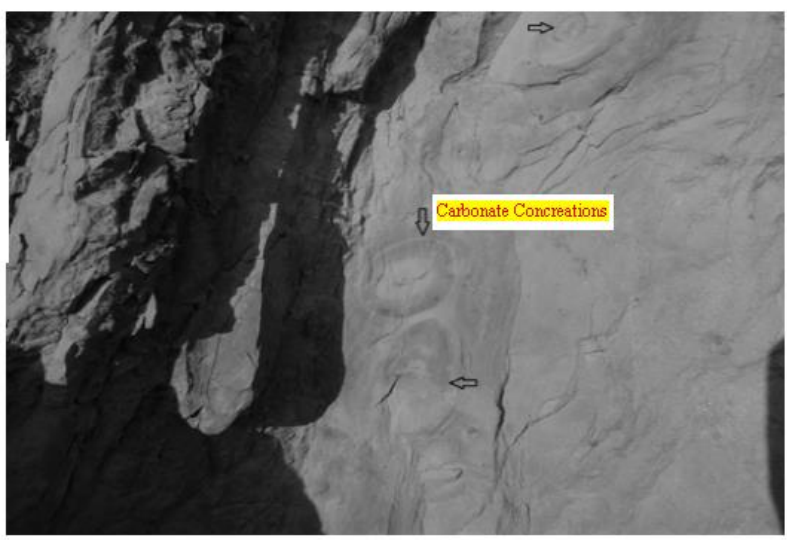

Fig. 7 The carbonate concreations in Nagri shale, Maidan, Pakistan (Yasin, 2014).

\subsubsection{Alluvium}

The alluvium is well exposed in Khirik (Fig. 2). The alluvial also forms terraces. The project area forms inundated stream terraces and man made terraces (Yasin, 2014).

\subsection{Petrography}

The petrography of rock samples indicate that the multitudinous of quartz $(23 \%$ - $45 \%$ in the Murree Formation, $26 \%$ - 45\% in the Nagri Formation and $27 \%-42 \%$ in the Dhok Pathan Formation), feldspar (3\% - 9\% in the Murree Formation, 4\% - 14\% in the Nagri Formation and $8 \%-13 \%$ in the Dhok Pathan Formation) and rock fragments (34\%

- 56\% in the Murree Formation, 31\% - 43\% in the Nagri Formation and $29-41 \%$ in the Dhok Pathan Formation) are in bulk (Table. 1; Table. 2). The accessory minerals (Few traces - up to 3\%) exist in exiguous amount (Table. 1; Table. 2). The minerals were clumped and coerced in to regularity during diagenesis. The matrix $(0-7 \%$ in the Murree Formation, 2\% - 16\% of the Nagri Formation and 3\% - 15\% of the Dhok Pathan Formation) and cement ( $4-15 \%$ in the Murree Formation, $4 \%$ $-13 \%$ in the Nagri Formation and $4 \%-18 \%$ in the Dhok Pathan Formation) forms the considerable volume of sandstone. So, the essential minerals, accessories, matrix and cement have incommensurate abundance (Table. 1; Table. 2).

\subsubsection{Quartz}

Among quartz the monocrystalline and polycrystalline grains with some undulation are common. The grains vary in outline from very angular, angular to rod shaped as well as sub rounded to rounded (Yasin, 2014). Few quartz grains are stretched and strained. The gains with sharp, tangential and suture contacts are visible. The fracturing, hematite coating, stylolitization (Fig. 8D), dissolution and zircon invasions are important characteristics of quartz (Yasin, 2014).

\subsubsection{Feldspar}

The feldspar in rock samples exist in both forms as alkali and plagioclase feldspar (Table. 1; Table. 2). The alkali feldspar includes orthoclase, microcline, microperthite and perthite while the plagioclase feldspar includes albite (Table. 1; Table. 2). The zoning (Fig. 8E), twinning, albitization and exsolution are important characteristics of feldspar. The myrmekite texture and pericline twinning are visible in few feldspar grains (Yasin, 2014). The K-feldspar has a high concentration in the Nagri and Dhok Pathan Formations as compared to the Murree Formation (Table. 1; Table. 2).

\subsubsection{Rock Fragments}

The rock fragments abounds in rock samples (29\% - 56\%). The mafic volcanic rocks, biotite grade schists, mica schists, graphitic schists, quartzite, granite, limestone, bioclasts, dolomite, marble, sandstone, siltstone and mudstone galore in the rock (Table. 1; Table. 2).. The mafic rock fragments possess porphyritic and coarse chondrite texture (Fig. 8B). The quinqualoculina (Fig. 8A) in bioclast, cone in cone structure (Fig. 8c), rhomb and scars as well as the compositional sector zonning (Fig. 8F) form the texture of carbonate rock fragment. 


\subsubsection{Accessories}

There is a little disparity among the concentration of biotite and muscovite (Tables. 1; Table. 2). The minerals biotite (few traces to $3 \%$ ), muscovite (few traces to $2 \%$ ), chlorite (few traces to $1 \%$ ), hornblende (few trace to $1 \%$ ) and tourmaline (few traces) are numerated as accessories. The biotite and muscovite grains are deformed. The tourmaline, zircon (few traces to 1\%), hematite (few traces to $1 \%$ ) and pyrite (few traces) are the opaque minerals in rock samples. The pleochroic haloes in the zircon are harbinger of radioactivity. The rutile forms only a few traces (Table. 1; Table. 2)

\subsubsection{Cement and matrix}

The matrix in rock samples varies from very low, even not 1 iota in one rock sample (hence designated as matrix free) to $16 \%$. On the other hand the calcite, chalcedony (Fig. 8G) with "plumose texture" and pore filling chert forms the cement (Table. 1; Table. 2).

Table 1: The modal analysis of the rocks in project area (Yasin, 2014).

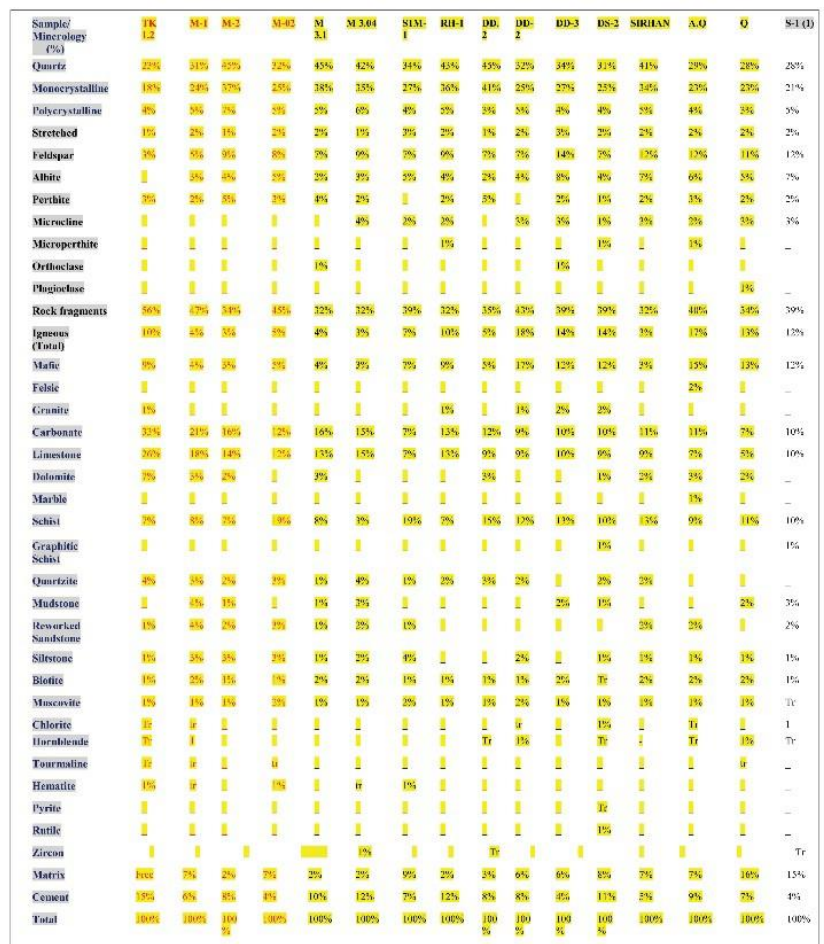

Table 2: The modal analysis of the rocks in project area (Yasin, 2014).

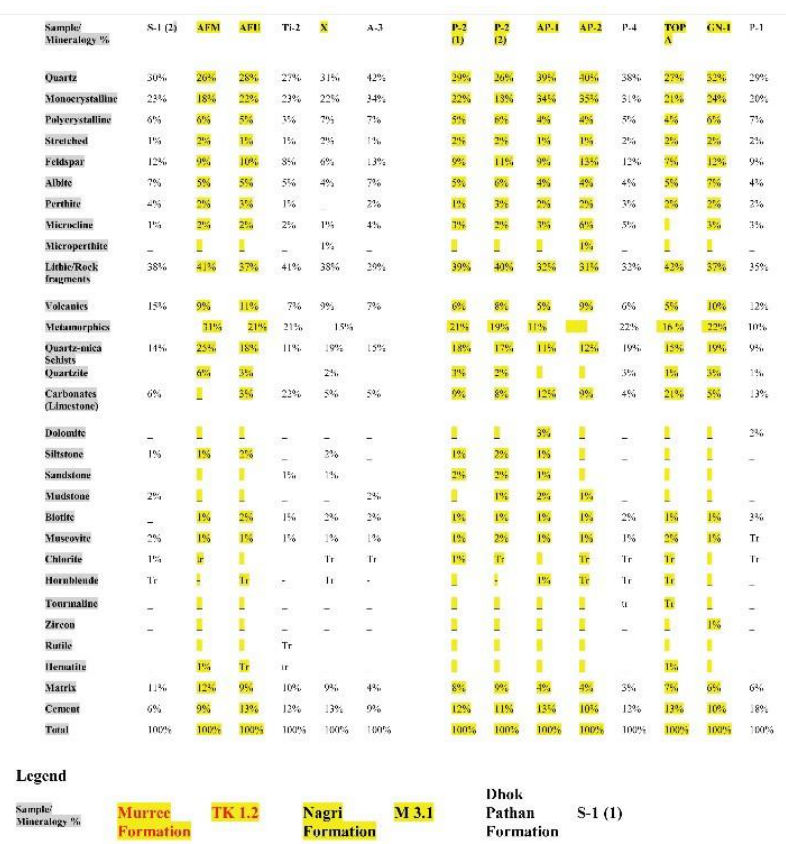

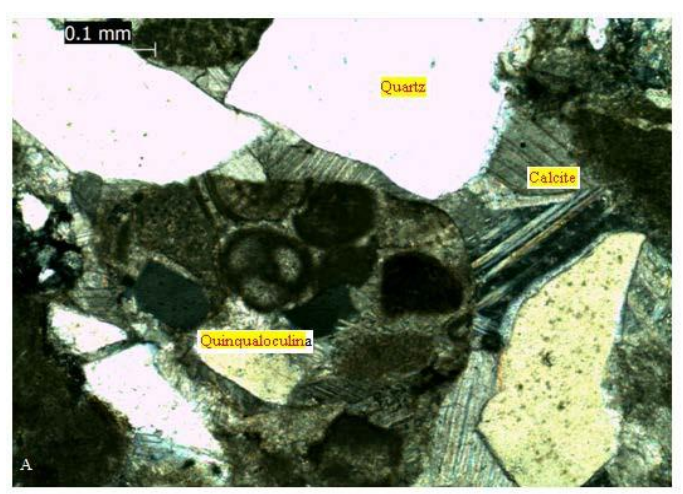
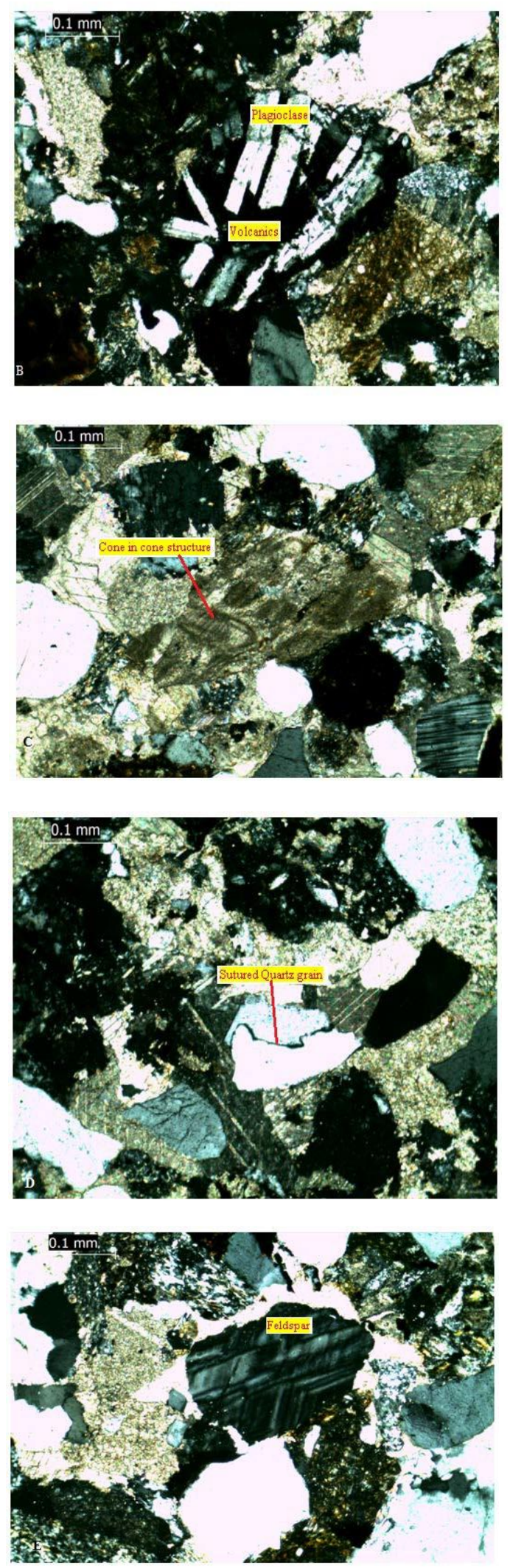

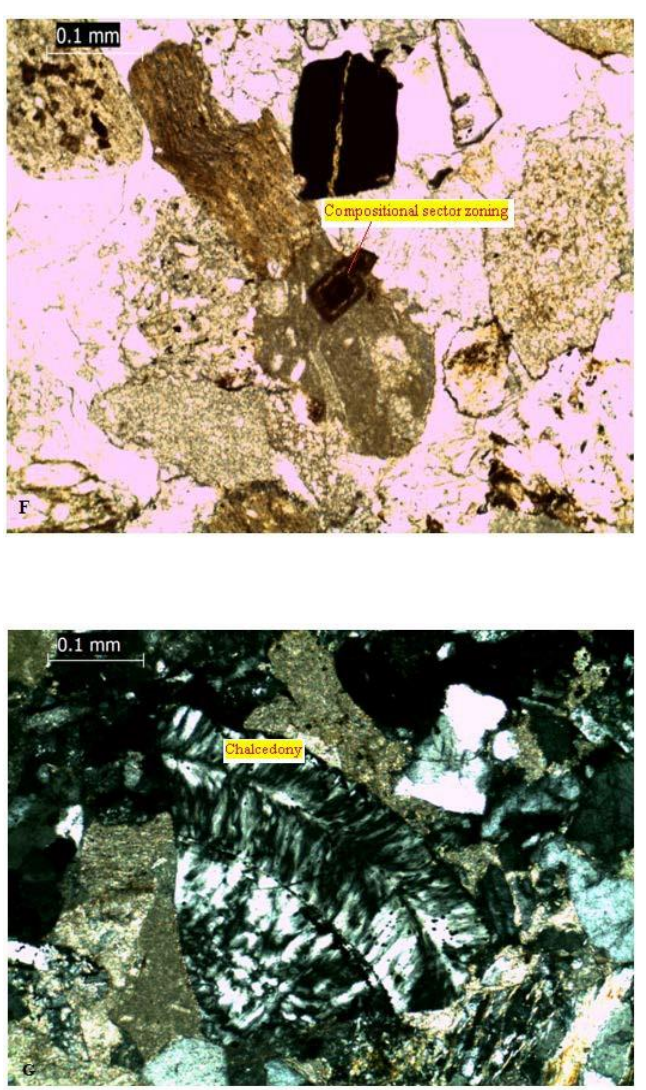

Fig 8. The photomicrographs showing (A) fossil quinqualoculina, (B) volcanic rock fragments having coarse chondrite texture, $(\mathrm{C})$ cone in cone texture in carbonate fragments, (D) stylolitic texture in sutured quartz, (E) zoning in feldspar, (F) compositional sector zoning in dolomite clast, (g) chalcedony.

\subsubsection{Sandstone classification}

The modal mineralogical data (Table. 1; Table. 2) has been used to classify rocks of the area. The rock samples in the project area are classified on QFL triangular plot (Fig. 9a; Fig. 9b; Fig. 9c) as the lithic arenites and lithic graywackes following the classification scheme (Blatt and Tracy, 1996). The matrix is in profusion in lithic arenites (below 5\%) as compared to the lithic graywackes with matrix above 5\% (Yasin, 2014). Moreover, in lithic graywackes the mafic igneous rock fragments are abundant. Beside these, the lithic arenites are further classified as phyllarenites and calclithites (Fig. 9d) on the equilateral triangle (Folk, 1968). The volcanic rock fragments are exiguous in lithic arenites as revealed by their absence in rock samples (Fig. 9d).
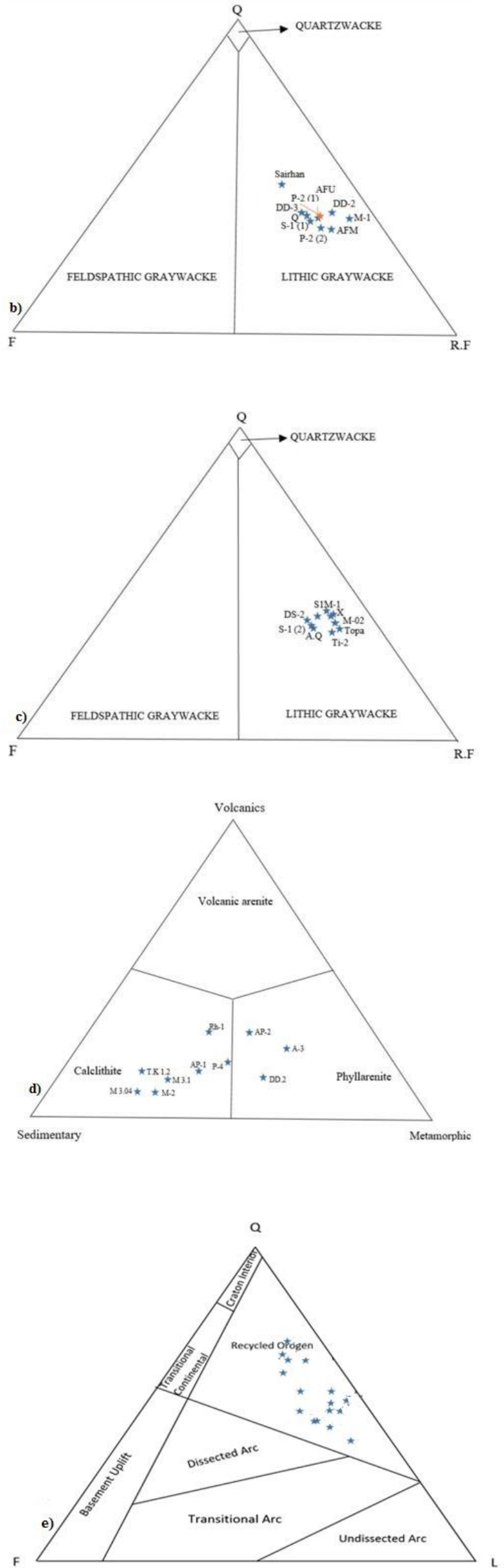

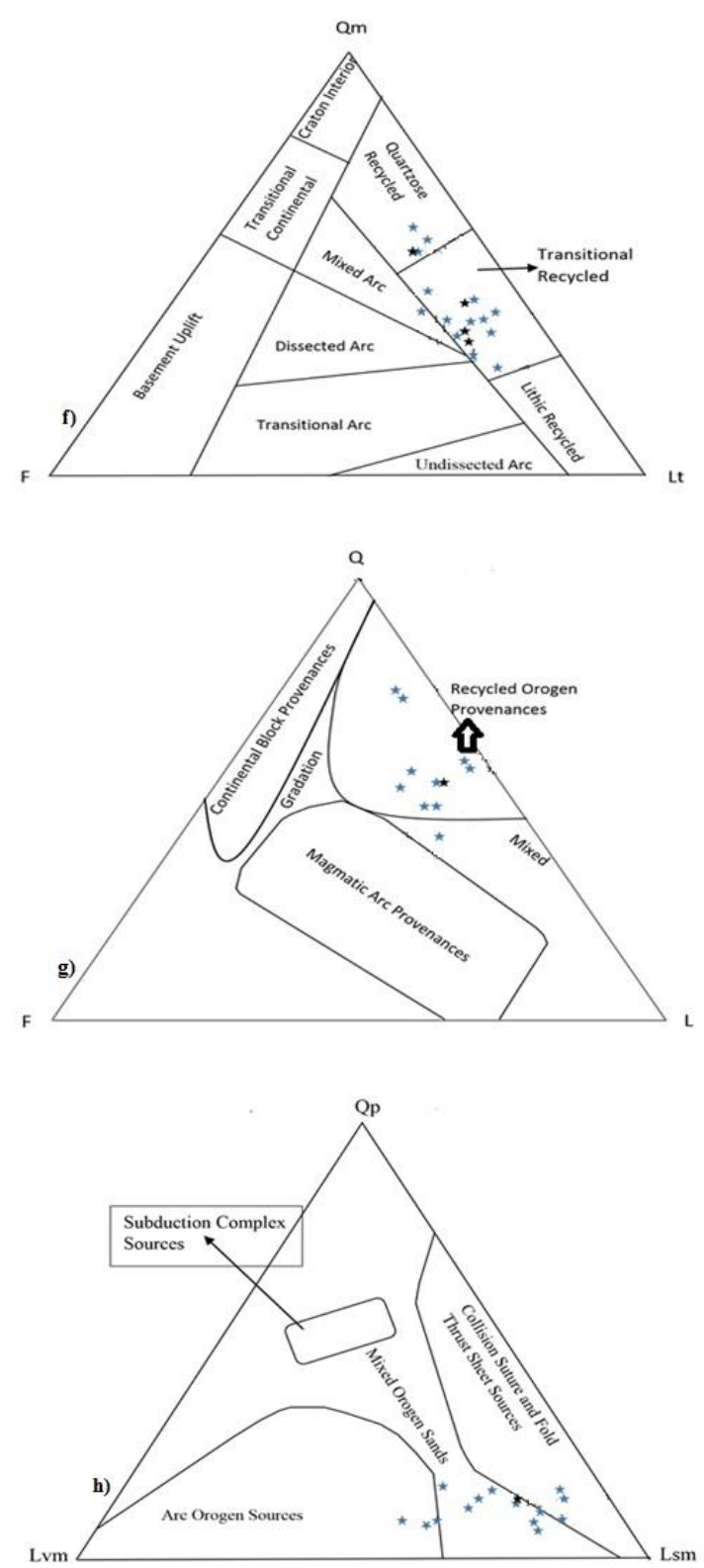

Fig. 9 Showing sandstone classification diagrams (a), (b) and (c) in the area after (Blatt and Tracy, 1996), (d) The subdivision of litharenites after (Folk, 1968). (e) and (g) are the provenance determining diagrams after (Dickinson et al., 1983; Dickinson, 1985). (f) The tectonic settings of sandstone after (Dickinson, 1983; Dickinson, 1985), (h) Qp-Lvm-Lsm ternary plot after (Dickinson and Suczek, 1979; Yasin, 2014). Quartzose grains $(\mathrm{Qt}=\mathrm{Qm}+\mathrm{Qp})$, Unstable Lithic Fragments $(\mathrm{L}=$ $\mathrm{Lv}+\mathrm{Ls})$. Total lithic fragments $(\mathrm{Lt}=\mathrm{L}+\mathrm{Qp})$. Qt $=$ Total quartzose grains, $\mathrm{Qm}=$ Monocrystalline quartz, $\mathrm{Qp}=$ Polycrystalline quartz, $\mathrm{F}=$ Total feldspar grains, $\mathrm{L}=$ Total unstable lithic fragments, $\mathrm{Lv}=$ Volcanic / metavolcanic lithic fragments, $\quad$ Ls $=$ Sedimentary metasedimentary lithic fragments, Lt = Extrabasional detrital limestone (not included in L or Lt).

\subsubsection{Provenance and tectonic settings}

Similarly, the modal analysis of the rocks (Table. 1; Table. 2) has been used to find the provenance and tectonic settings of the region on the QFL (Fig. 9e; Fig.9g) equilateral triangular diagram (Dickinson et al., 1983; Dickinson, 1985). The recycled orogenic provenance has been found in this scheme of study. The fundamental requisite of research also includes tectonic settings in different orogenic provenances. For this purpose, the Qm-F-Lt (Fig. 9f) plot favours quartzose recycling, transitional recycling as well as reflects some possibility of mixed sources in different tectonic regions (Dickinson et al., 1983; Dickinson, 1985). Similarly, the Qp-Lv-Lsm (Fig. 9h) ternary diagram after Dickinson and Suczek, 1979 is also expedient in provenance analysis and has revealed collision sutured fold and thrust sheet sources, arc orogen as well as mixed orogen resources.
The provenance of rock samples has also been deduced through mineralogy. For example, the remote mountaineous recesses have yielded quartz grains with rounded outline as compared to the angular grains (Yasin, 2014). Similarly, the stretched and undulose quartz grains have igneous and metamorphic provenances. The chert in the pore spaces of rocks has favoured the subduction complex provenances (Boggs, 2006). Similarly, the zoned feldspars (Fig. 8E) are dislodged from granites of the Himalayan mountaineous belts and the myrmekite texture in plagioclase also favours igneous origin. The lithic fragments in the rock samples indicate a high relief source area adjacent to the magmatic arcs and suture belts. The fossil quinqualoculina (Fig. 8a) and the cone in cone structure (Fig. 8c) in carbonate fragments reveals that the Himalayan orogeny has warred out the Eocene Formations and carbonate rocks during early diagenesis (Kamran et al., 2006). The recrystallization of fossils (Yasin, 2014) indicates a diagenetic change.

Similarly, the abundance of metamorphic rock fragments in the Nagri and Dhok Pathan Formations as compared to the Murree Formation (Table 1: Table 2) indicates the Himalayan epirogeny along the MCT during late stages of collision. However, the absence of volcanic arenites (Fig. 9d) indicates their scarcity in the Indus-Tsangpo suture zone at the time of deposition of the rocks.

The fracturing, dissolutions, stylolitization (Fig. 8D), clay minerals authigenesis, calcite (Fig. 8A) and silica (Fig. 8G) cementation indicates diagenetic changes in the rocks

Anyhow, the modal data also revealed the derivation of detritus from the rising Himalayas in north of the area.

\subsection{Conclusions}

The project area possesses Miocene to late Pliocene detrital rock sequences beside the eastern limb of Hazara Kashmir Syntaxis (HKS) in the Sub-Himalayas. The area is deformed to the regional folds, fault and composite landslides. The Riasi fault is the only thrust fault of the area. The planner bedding and ripple marks indicates that the sediments have been jostled by flow towards south from north. The pebbles also show imbrications subservient to the flow direction during deposition of rocks. The warm, semiarid and arid climes under hydromorphic conditions are suitable for the origin of calcareous concreations (Gile et al., 1965; Kraus, 1999). The coarse lithologies were deposited by the floundering velocities of channel. The fine lithologies (clays, shale) are deposited by means of inundated meandering, braided or other stream patterns. The petrographic analysis of area indicates that the essential minerals, accessories, matrix and cement resided inside the rock. The modal mineralogical data reveals that the lithic arenites and lithic graywackes are sourced from the rising Himalayas in the north of the area. Similarly the wood fossils, leaf imprients, conglomerates, the pieces of granite and the presence of hematite etc in the rocks are the prima facie for the continental origin of rocks.

\section{References}

[1] Akhter, Q. J., Xue. C., Lap. T. T., Aiying, W., and Ghaffar, A., (2015). Miocene sandstone of Murree Formation, Rawalakot, Azad Kashmir, Pakistan: Geotechnical properties evaluation of Geo-material. International Journal of Research in Engineering \& Technology, 3(3): 51-60.

Baig, M. S., Lawrence, R. D., 1987. Precambrian to Early Paleozoic Orogenesis in the Himalaya. Kashmir Journal of Geology, 5: 1-22.

[3] Blatt, H., Tracy, R. (1996). Petrology, Igneous, Sedimentary and Metamorphic. 2nd end., W. H. Freeman Pub. New York, 497 pp.

[4] Boggs, S., (2006). Principles of Sedimentology and Stratigraphy. 4 rth ed., J. Univ. Oregon. Pearson education, Inc, NJ. 662 pp.

[5] Chaudhary, M. N., Ashraf, M., (1980). The volcanic rocks of Poonch district, Azad Kashmir. Special Issue, Geology Bulletin University Peshawar, 131(152): 121-128.

[6] Cotter, G. De. P., 1933. Geology of part of Attock district west of longitude $72^{\circ} 45^{\prime}$ E. Geological Survey India, Memoires, 55(2): 63-161.

[7] Dickinson, W. R., Beard, L.S., Brakenridge, G. R., Erjavek, J. L., Ferguson, R. C.,Inman, K. F., Knepp, R. A., Lindberg F. A., and Ryberg. P. T., 1983. Provenance of North American Phanerozoic sandstones in relation to tectonic setting. Geological Society of America, Bulletin, 94: 222235. 
[8] Dickinson, W. R., 1985. Interpreting provenance relations from detrital modes of sandstones. In: Zuffa, G. G. (eds.), Provenance of Arenites Dordrecht. The Netherlands, Reidel Publishing Company. NATO, Advance. Studies Institute Series, 148: 333-361.

[9]

Dickinson, W. R., Suczek, C. A., 1979. Plate tectonics and sandstone composition. American Association of Petroleum Geologists Bulletin, 63: 2164-2182.

[10]

Gile, L.H., Peterson, F.F., Grossman, R.B., 1965. The $\mathrm{K}$ horizon-a master soil horizon of carbonate accumulation. Soil Science, 99:74-82.

[11] Kamran, S. M., Khan, M. S., Siddiqi, M. I., 2010. Petrography of Sandstone of Molasse Deposits (Rawalpindi Group) And Their Tectonic Setting From Khairimurat Area, Potwar Sub-basin,Pakistan. Pakistan Journal of Hydrocarbon Research. 20:11-17.

[12] Kamran, S. M., Khan, M. S., Siddiqi, M. I., Munir, M., 2006. Micropalaeontology and Depositional Environment of the Early Eocene Margala Hill Limestone and Chor Gali Formation of the Khairi Murat Range,Potwar Basin, Pakistan. Pakistan Journal of Hydrocarbon Research. 16: 51-57.

[13] Kraus, M.J., 1999. Paleosols in clastic sedimentary rocks: their geological applications. Earth Science Reviews, 47: 41-70.

[14] Lewis, G. E., 1937. A new Siwalik correlation (India). American Journal Science Series, 5, no. 195, 33: 191-204.

[15]

Shah, S.M.I., (1928). Stratigraphy of Pakistan. Memoirs of the Geological Survey of Pakistan, 22: 293298.

[16] Wadia, D. N., (1928). The geology of the Poonch state (Kashmir) and adjacent portions of the Punjab. Memoirs of the Geological Survey of India, 51(2): 185370.

[17] Wynne, A. B., 1874. Notes from a progress report on the geology of parts of the upper Punjab. Geological Survey of India, Record, 6 (3): 59-64.

[18] Yasin, M., 2012. Structure and Stratigraphy of Chattroh, Siakh, Kanger, Mandhal and Palina areas of Azad Kashmir and Pakistan, Unpublished Thesis, Institute of Geology, University of Azad Jammu and Kashmir, Pakistan. pp. 39

[19]

Yasin, M., (2014). Petrography and Sedimentology of Neogene sediments in Mang and adjoining areas in the Sub Himalayas, Azad Jammu and Kashmir, Pakistan, Unpublished MS Thesis, University of Azad Jammu and Kashmir, Muzaffarabad, pp. 213. 